\title{
61. OPAQUE MINERALOGY OF ALTERED BASALTS FROM HOLE 417A OF IPOD LEG 51
}

\author{
Daniel Plasse, Department of Geology, Dalhousie University, Halifax, Nova Scotia B3H 3J5, Canada
}

\begin{abstract}
A detailed opaque mineralogical investigation of five samples from IPOD Leg 51, Hole 417A, shows that characteristic hydrothermal alteration textures are not present in the titanomaghemites. This evidence supports an earlier suggestion that the high degree of alteration observed in Hole $417 \mathrm{~A}$ basalts is due to intensive weathering (halmyrolysis) and not to hydrothermal alteration at temperatures approaching $150^{\circ} \mathrm{C}$. The high magnetic intensity of the Site 417 basalts may be related in part to a high abundance of magnetic minerals ( $1.4 \%$ average volume), but more samples are required to verify this suggestion.
\end{abstract}

\section{INTRODUCTION}

The combination of ore microscopy and rock magnetism has proven to be an effective way of characterizing secondary alteration processes which occur in upper oceanic Layer 2 (Irving, 1970; Ade-Hall et al., 1976a; Hall and Ryall, 1977). An optical examination of the magnetic mineralogy defines the type of oxidation which has taken place (low temperatures, hydrothermal, or deuteric), while Curie temperature measurements provide a quantitative estimate of the degree of oxidation.

With rare exceptions, sea-floor weathering at no more than a few tens of degrees centigrade is by far the dominant alteration process to act on Layer 2 as a whole (Hall and Ryall, 1977). Evidence for zeolite facies metamorphism and high temperature (initial cooling) alteration is rare (Hall and Ryall, 1977).

The 108-m.y.-old basalts recovered during IPOD Leg 51 from Hole $417 \mathrm{~A}$ (located at about $25.1^{\circ} \mathrm{N}, 68^{\circ} \mathrm{W}$ in the North Atlantic) are interesting because they are reported to be both highly altered and to have an unusually strong remanent magnetization (Donnelly et al., 1977). The main purpose of this investigation was to perform a routine opaque mineralogical examination on a small number of samples of the altered basalts from Hole 417A in the hope that it would tell something about their alteration history. At the same time, the opaque mineralogy data could be compared with results from DSDP Legs 34 and 37 to see if there were any abnormalities in the abundance or type of magnetic phases present at Site 417 which might be related to the strong magnetization.

\section{METHODS}

Microscopic observations were performed on a Zeiss Universal microscope using an oil-immersion objective at a total magnification of 1375 diameters. All of the magnetic measurements were conducted at Dalhousie University using equipment and techniques described elsewhere (Ade-Hall et al., 1976b; Hall and Ryall, 1977).

\section{OPAQUE MINERALOGY}

The magnetic minerals of the basalts from Hole 417A are titanomaghemites (cation-deficient titanomagnetites) with an off-white color and high reflectivity. The titanomaghemite grains occur as microlitic phases in the basalt groundmass (Plate 1, Figure 1). Phenocrysts of titanomaghemite are absent but chains of interlocking microlites are common (Plate 1, Figure 2). Granulation, the typical hydrothermal alteration texture of a titanomagnetite (Ade-Hall et al., 1971; Abdel-Aal, 1977) was not observed in any of the samples from Hole $417 \mathrm{~A}$. Other textures were observed, such as patchy color lightening, cracking, and occasional corrosion and partial replacement of titanomaghemite by a yellow phase.

The titanomaghemites of the Hole $417 \mathrm{~A}$ basalts are rather fine-grained and moderately abundant. The average grain diameter is about $5 \mu \mathrm{m}$ at Hole $417 \mathrm{~A}$, in contrast with 14.4 $\mu \mathrm{m}$ for Leg 34 and $3.5 \mu \mathrm{m}$ for Leg 37 basalts. The average volume percentage of titanomaghemite for the Hole 417A basalts is 1.4 , in contrast with 2.35 in Leg 34 and 0.4 in Leg 37 .

\section{MAGNETIC PROPERTIES}

Values of $\mathrm{J}_{\mathrm{NRM}}$ and susceptibility of the Hole $417 \mathrm{~A}$ basalts tend to be higher than those observed in basalts from Legs 34 and 37 (Table 1). The five basalts studied here from Hole $417 \mathrm{~A}$ had an average magnetization of $63.6 \times 10^{-4}$

TABLE 1

Summary of Magnetic and Opaque Mineralogical Data for Five Samples From IPOD Leg 51, Hole 417A, Altered Basalts

\begin{tabular}{|c|c|c|c|c|c|c|c|c|c|c|c|}
\hline $\begin{array}{c}\text { Sample } \\
\text { (Interval in } \mathrm{cm} \text { ) }\end{array}$ & 1 & 2 & 3 & 4 & 5 & 6 & 7 & 8 & 9 & 10 & 11 \\
\hline $25-1,57$ & 20 & 3.56 & 58.8 & 350 & 0.31 & 6.8 & 8.6 & 200 & 1.4 & 3.5 & 0.90 \\
\hline $26-2,10$ & 30 & 1.36 & 52.9 & 300 & 0.57 & 9.8 & 5.4 & 160 & 1.2 & 4.5 & 0.77 \\
\hline $27.2,15$ & 35 & 1.83 & 20.7 & 347 & 0.40 & 7.6 & 2.7 & 185 & 0.8 & 2.8 & 0.88 \\
\hline $28-3.119$ & 55 & 1.79 & 111.8 & 290 & 0.37 & 3.2 & 34.9 & 300 & 1.7 & 4.1 & 0.74 \\
\hline $29-1,86$ & 65 & 0.46 & 73.6 & 355 & 0.41 & 11.5 & 6.4 & 80 & 1.8 & 12,4 & 0.91 \\
\hline Average & - & - & 63.6 & 328 & 0.41 & 7.8 & 11.6 & 185 & 1.4 & 5.5 & 0.81 \\
\hline
\end{tabular}


$\mathrm{emu} / \mathrm{cm}^{3}$ (vs. $41 \times 10^{-4} \mathrm{emu} / \mathrm{cm}^{3}$ for Leg 34 and $36.6 \times 10^{-4}$ emu/cm $\mathrm{cm}^{3}$ for Leg 37; Ade-Hall et al., 1976b; Ryall et al., 1977 ; p. 692), a value somewhat lower than the average value obtained from shipboard measurements. Keeping in mind that only five samples were measured in this study, and one of them (Sample 417A-28-3, $119 \mathrm{~cm}$ ) had a very high magnetization of $111 \times 10^{-4} \mathrm{emu} / \mathrm{cm}^{3}$, little significance should be attached to the difference in average magnetic intensities reported here and for the results of the shipboard study (Donnelly et al., 1977).

The average Curie temperature for the five Hole 417A basalts is $328^{\circ} \mathrm{C}$, implying that the titanomagnetites are highly cation deficient $(\bar{z}=0.84)$. There is no obvious correlation between secondary oxidation and basement depth or $\mathrm{K}_{2} \mathrm{O}$ content. All of the strong field heating curves for the Hole 417A basalts are highly irreversible, further evidence for the high oxidation state of the magnetic minerals.

Values of $\mathrm{J}_{\mathrm{sat}}$, median destructive field, and $\mathrm{Q}$ ratio are all similar to those observed for the Leg 37 basalts. In the case of saturation magnetization, this is quite interesting because one would expect a high $\mathbf{J}_{\text {sat }}$ to accompany the high $\mathbf{J}_{\text {NRM }}$ and high susceptibility observed at Hole 417A. This apparent discrepancy in the magnetic data might be examined more closely in further magnetic investigations of the Hole $417 \mathrm{~A}$ basalts.

There is no obvious connection between the high remanent and induced magnetizations and the type of magnetic minerals present in Site 417 basalts. There is a hint of a direct correlation between magnetic intensity and titanomagnetite abundance (Table 1) but more than five samples are needed to be able to state this with confidence. In addition, many Leg 34 samples (Ade-Hall et al., 1976b; Table 1) have titanomagnetite volume percentages greater than or equal to that observed for the Hole $417 \mathrm{~A}$ basalts without exhibiting high magnetic intensities. During further investigations into the origin of the high magnetic intensity of basalts from Hole $417 \mathrm{~A}$, other investigators should allow for differences in titanomagnetite volume percentages as well as other possible causes.

\section{CONCLUSIONS}

The absence of characteristic hydrothermal alteration textures in the opaque oxides of Hole 417A basalts suggests that secondary alteration took place at temperatures well below $150^{\circ} \mathrm{C}$ and at probably only a few tens of degrees centigrade. These results are consistent with the suggestion of Donnelly et al. (1977) that the high degree of alteration observed in Hole $417 \mathrm{~A}$ was primarily due to an intense halmyrolysis of basalts during a long period of direct exposure to sea water.

\section{ACKNOWLEDGMENTS}

A special thanks is extended to Dr. Donnelly for kindly providing the samples for this investigation; J. M. Hall for his critical review of the manuscript and helpful suggestions; and to M. A. Annand for her patience in retyping the final manuscript.

\section{REFERENCES}

Abdel-Aal, O.Y., 1977. Alteration of opaque minerals and the magnetization and magnetic properties of volcanic rocks in a drill hole from an active geothermal area in the Azores, $\mathrm{Ph} . \mathrm{D}$. thesis, Dalhousie University, Canada.

Ade-Hall, J.M., Palmer, H.C., and Hubbard, P.T., 1971. The magnetic and opaque petrological response of basalts to regional hydrothermal alteration, Geophys. J. Roy. Astron. Soc., v. 24 , p. 137-174.

Ade-Hall, J.M., Fink, L.K., and Johnson, H.P., 1976a. Petrography of opaque minerals, Leg 34. In Hart, S.R., Yeats, R.S., et al., Initial Reports of the Deep Sea Drilling Project, v. 34: Washington (U.S. Government Printing Office), p. 485-494.

Ade-Hall, J.M., Johnson, H.P., and Ryall, P.J.C., 1976b. Rock magnetism of basalts, Leg 34. In Hart, S.R., Yeats, R.S., et al., Initial Reports of the Deep Sea Drilling Project, v. 34: Washington (U.S. Government Printing Office), p. 459-468.

Donnelly, T.W., et al., 1977. Mid-ocean ridge in the Cretaceous, Geotimes, v. 22, p. 21-23.

Hall, J.M., and Ryall, P.J.C., 1977. Rock magnetism of basement rocks, Leg 37. In Aumento, F., Melson, W.G., et al., Initial Reports of the Deep Sea Drilling Project, v. 37: Washington (U.S. Government Printing Office), p. 489-501.

Irving, E., 1970. The Mid-Atlantic Ridge at $45^{\circ} \mathrm{N}$, XIV. Oxidation and magnetic properties of basalt, review and discussion, Canadian Journal of Earth Sciences, v. 7, p. 1528-1538.

Ryall, P.J.C., Hall, J.M., Clark, J., and Milligan, T., 1977. Magnetization of oceanic crustal layer 2 - results and thoughts after DSDP Leg 37, Canadian Journal of Earth Sciences, v. 14, p. 684-706. 


\section{PLATE 1}
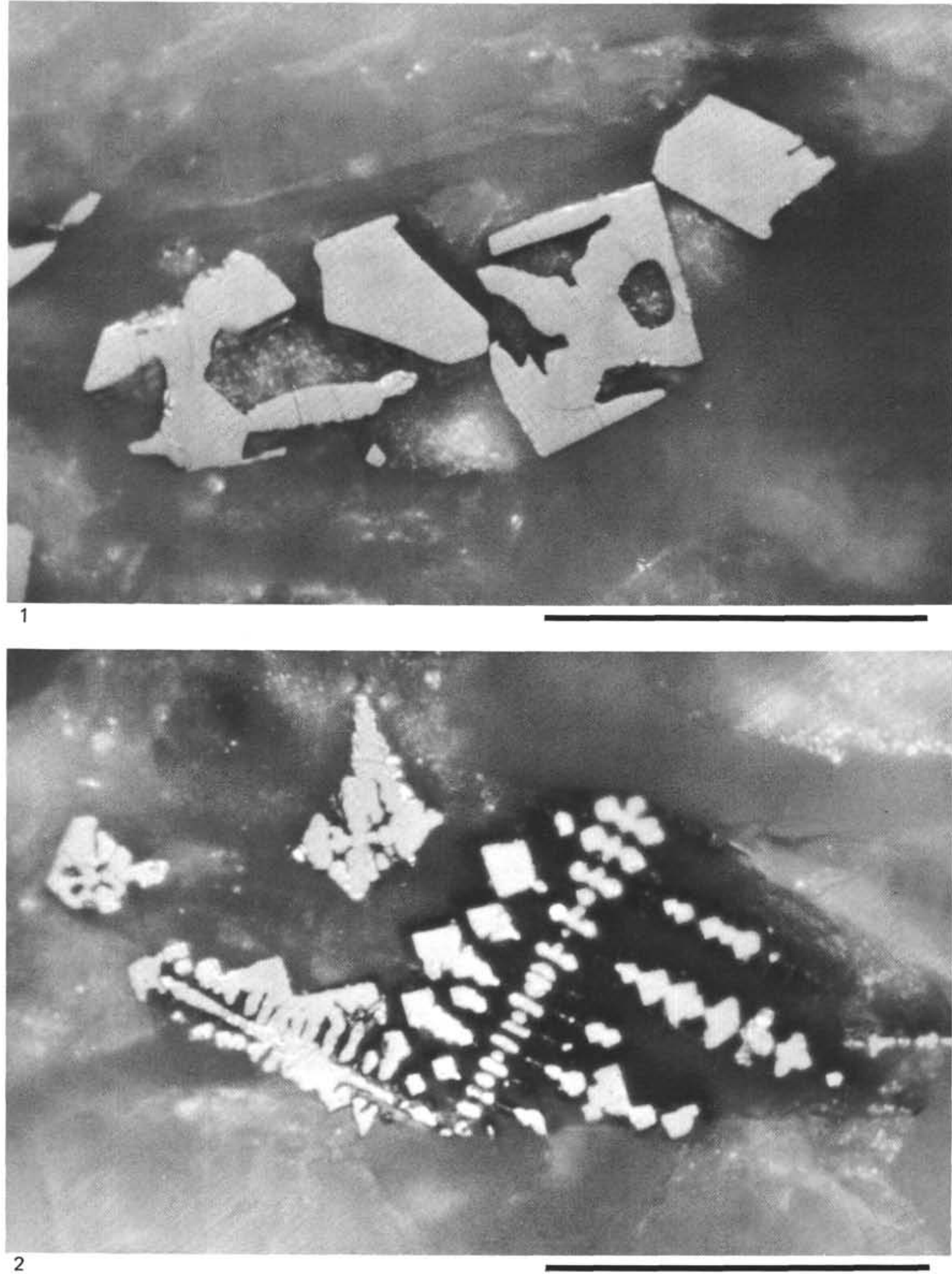

Skeletal Titanomaghemites From Hole 417A

(bar width in both paragraphs $=15 \mu \mathrm{m}$ )

Figure 1 Typical skeletal grain, Sample 417A-29-1, $86 \mathrm{~cm}$.

Figure 2 Chains of interlocking microlites showing slight corrosion and partial replacement of the titanomaghemite by a yellow phase (i.e., the light areas in the plate), Sample $417 \mathrm{~A}-28-3,119 \mathrm{~cm}$. 